\title{
Study on the Envelop Construction of Rural Building for Increasing Solar Energy Heat Utilization Efficiency
}

\author{
Guochen Sang ${ }^{1, a}$, Yan Han ${ }^{2, b}$, Yiyun Zhu ${ }^{3, c}$,Qin Zhao ${ }^{4, d}$ \\ ${ }^{1}$ Associate Professor, School of Civil Engineering and Architecture, Xi'an Univ. of Technology, \\ China. \\ ${ }^{2}$ Postgraduate, School of Civil Engineering and Architecture, Xi'an Univ. of Technology, China. \\ ${ }^{3}$ Associate Professor, School of Civil Engineering and Architecture, Xi'an Univ. of Technology, \\ China. \\ ${ }^{4}$ Associate Professor, School of Civil Engineering and Architecture, Xi'an Univ. of Technology, \\ China. \\ a'E-mail: sangguochen@xaut.edu.cn, be-mail:hanyan2015615@outlook.com, ${ }^{\mathrm{c} E}$-mail: \\ zyyun@xaut.edu.cn, ${ }^{\mathrm{d} E}$-mail: zhaoqin6688@xaut.edu.cn
}

\section{Highlights}

- This study developed the energy saving construction system to improve the solar thermal efficiency.

- Indoor design and calculation temperature of Zhongwei city of Ningxia province was provided.

- Heat transfer coefficient of different non-uniform wall construction were proposed.

- The effect of direct-gain solar heat collecting system on indoor thermal comfort was ascertained.

Keywords: Ningxia province, rural residence, solar energy, energy saving construction.

\begin{abstract}
The investigation and testing of the rural building in Ningxia found that the indoor thermal environment of existing residential buildings was not enough to meet the requirement of local residents. Taking Zhongwei city of Ningxia province as study area, the energy saving construction system for solar energy heat utilization is studied by analyzing the factors of indoor thermal environment. Analysis results show that by using non-uniform wall construction of energy saving design and combined with the improvement design for direct-gain solar heat collecting system, improving the indoor thermal environment quality of local rustic residence effectively. The conclusions of this paper can provide reference for the optimization design of the rural residential buildings in the similar region.
\end{abstract}

\section{Introduction}

With the continuous improvement of the level of economy, the area of rural construction increase considerably, and the rural residents have higher requirements for indoor thermal comfort. However, almost all rural residences are self-built building in this region, the building energy saving has not been fully considered. The thermal performances of the building envelope are not ideal and the construction has defects in design. Thus, the indoor thermal status is significantly influenced by outdoor climate conditions. Taking Ningxia area for example, the region belongs to severe cold area, winter heating period of which up to 137 days [1], and the average air temperature approximate below zero $1.3{ }^{\circ} \mathrm{C}$, the relative humidity approximate $30 \%$, so the climate is dry and cold. Average sunshine hours in Ningxia are more than 3796 hours. The accumulated solar radiation of year is $5893 \mathrm{MJ} / \mathrm{m}^{2}$ [2]. Therefore, the rich solar energy resources for the local rural residential winter heating provide energy guarantee [3,4].This paper taking the rural residences in Zhongwei city of Ningxia for example, the optimization analysis of the energy saving construction of the local rural residences has been done on the basis of improving the solar thermal efficiency. 


\section{Basic Situation of local Existing Residential}

There are two main existing residences in Zhongwei city of Ningxia province, which are mainly traditional civil construction residence and new brick masonry constructions residence, as showed in Fig.1. Architectural and constructive information of the two types of residences are shown in Table 1 . and Table 2.

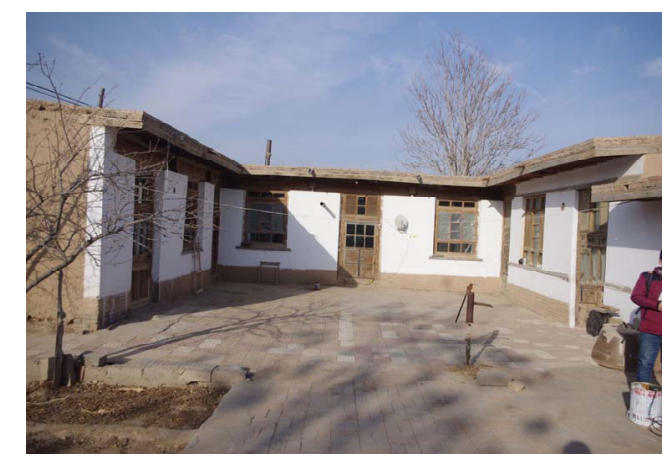

(a) Traditional civil residence

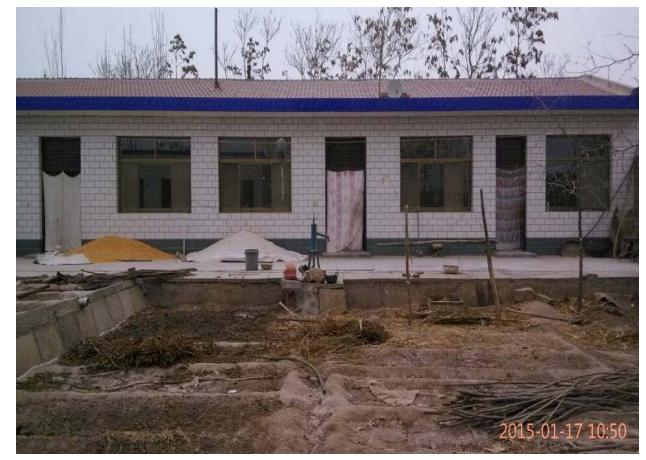

(b) New brick masonry residence

Fig.1 Two typical residences

Table 1. Building information of local existing residences

\begin{tabular}{|c|c|c|c|c|c|}
\hline & $\begin{array}{c}\text { Building area } \\
{\left[\mathrm{m}^{2}\right]}\end{array}$ & $\begin{array}{c}\text { Building height } \\
{[\mathrm{m}]}\end{array}$ & $\begin{array}{c}\text { South window } \\
\text { to wall ratio }\end{array}$ & $\begin{array}{c}\text { Shape } \\
\text { coefficient }\end{array}$ & Layout form \\
\hline $\begin{array}{c}\text { Traditional } \\
\text { civil }\end{array}$ & 175.07 & 3.0 & 0.1 & 0.46 & Peripheral layout \\
\hline $\begin{array}{c}\text { New brick } \\
\text { masonry } \\
\text { residence }\end{array}$ & 115.02 & 3.3 & 0.3 & 0.74 & $\begin{array}{c}\text { Determinant } \\
\text { layout }\end{array}$ \\
\hline
\end{tabular}

Table 2. Envelope construction performance of local existing residences

\begin{tabular}{|c|c|c|c|c|c|c|}
\hline & & Exterior wall & $\begin{array}{c}\text { Outside the } \\
\text { window }\end{array}$ & $\begin{array}{c}\text { Outside the } \\
\text { door }\end{array}$ & Roofing & Ground \\
\hline \multirow[t]{2}{*}{$\begin{array}{l}\text { Traditiona } \\
1 \text { civil } \\
\text { residence }\end{array}$} & $\begin{array}{c}\text { Constructio } \\
\mathrm{n}\end{array}$ & $\begin{array}{l}\text { Footing of wall is } \\
500 \mathrm{~mm} \text { high } \\
\text { solid clay brick } \\
\text { The wall is } \\
370 \mathrm{~mm} \text { thick } \\
\text { adobe masonry } \\
\text { East, west and } \\
\text { north to the grass }\end{array}$ & $\begin{array}{l}\text { Wooden } \\
\text { frame single } \\
\text { window } \\
\text { Plastic film } \\
\text { seal }\end{array}$ & $\begin{array}{l}\text { Single } \\
\text { wooden } \\
\text { door } \\
\text { Inside and } \\
\text { outside two }\end{array}$ & $\begin{array}{c}\text { Wooden beams } \\
\text { +wooden rafters } \\
+100 \mathrm{~mm} \\
\text { Barbara } \\
\text { reed }+100 \mathrm{~mm} \\
\text { mud } \\
+ \text { tile } \\
\text { Indoor }\end{array}$ & $\begin{array}{l}\text { Paving } \\
\text { clay } \\
\text { brick }\end{array}$ \\
\hline & $\begin{array}{c}\text { Heat } \\
\text { transfer } \\
\text { coefficient }\end{array}$ & 1.41 & 4.7 & 2.7 & 1.52 & 0.45 \\
\hline \multirow{2}{*}{$\begin{array}{l}\text { New brick } \\
\text { masonry } \\
\text { residence }\end{array}$} & $\begin{array}{c}\text { Constructio } \\
n\end{array}$ & $\begin{array}{l}370 \mathrm{~mm} \text { thick } \\
\text { solid clay brick } \\
\text { White plaster }\end{array}$ & $\begin{array}{l}\text { Single frame } \\
\text { aluminium } \\
\text { allov window }\end{array}$ & $\begin{array}{l}\text { Aluminium } \\
\text { alloy door }\end{array}$ & $\begin{array}{l}\text { Double hanging } \\
\text { tile roof } \\
\text { Indoor }\end{array}$ & $\begin{array}{l}\text { Paving } \\
\text { white } \\
\text { tiles }\end{array}$ \\
\hline & $\begin{array}{c}\text { Heat } \\
\text { transfer } \\
\text { coefficient }\end{array}$ & 1.54 & 6.4 & 6.4 & 1.74 & 0.33 \\
\hline
\end{tabular}

Note: The heat transfer resistance for the inner surface of wall is $0.11\left(\mathrm{~m}^{2} \cdot \mathrm{K}\right) / \mathrm{W}$, the outer surface of wall is $0.04\left(\mathrm{~m}^{2} \cdot \mathrm{K}\right) / \mathrm{W}$, insulation layer correction coefficient of thermal conductivity is 1.1 [5]; The thermal parameters of wall material can be determined by the literature [5], [6]. 
The Table 1 and Table 2 show that the new brick masonry residence made improvements in many ways on the basis of inheriting the advantages of traditional dwellings, including: community building layout combinations, south window to wall ratio, appearance, etc. Making the architectural form conforms to the modern development. However, it is still flawed building envelope thermal performance, doors and Windows performance, etc. which needs further study design.

\section{Indoor Thermal Environment Analysis of Residence}

Calculation of Subjective Temperature. As the evaluation standard of thermal environment in buildings: PMV index, effective temperature ET, operating temperature and so on due to the comprehensive consideration of temperature, humidity, wind speed and the average radiation temperature conditions, the calculation is too complex and not suitable for the design and application of rural areas of domestic [5,7]. According to the climate conditions, economic and technological status of Ningxia, the indoor thermal comfort standards of local rural residential buildings are expressed as indoor air temperature, which is the most effective and feasible. Therefore, this paper uses the subjective temperature as the evaluation standard of thermal comfort and the indoor temperature to design and evaluation.

Subjective temperature is determined under the given activities of the human body and clothing condition, as the standard environment temperature, when the subjective sense of a person is the same between a real environment and standard environment. Standard environment refers to the standard environment of gas flow velocity $0.1 \mathrm{~m} / \mathrm{s}$, a relative humidity of $50 \%$ and the air temperature is equal to the average radiant temperature of the uniform closed space [8]. Within the tolerance range, the relationship between the body's metabolism rate, clothing thermal resistance and subjective temperature can be expressed as Formula (1). [7,8]:

$$
t_{\mathrm{ob}}=33.5-3 R_{\mathrm{clo}}-\left(0.08+0.05 R_{\mathrm{clo}}\right) M
$$

In the formula (1), $t_{\mathrm{ob}}$ refers to the subjective temperature; $M$ refers to the metabolic rate of human activity; $R_{\text {clo }}$ refers to the thermal resistance of the clothing, which is calculated as Formula (2). and Formula (3).:

$$
\begin{aligned}
& R_{\text {clo }}=0.113+0.727 \sum R_{\mathrm{i}} \quad(\text { male }) \\
& R_{\text {clo }}=0.05+0.727 \sum R_{\mathrm{i}} \quad(\text { female })
\end{aligned}
$$

According to the 2015 winter investigation and testing data for climate characteristics of rural Ningxia , residential behavior, life habits, dress and other conditions, it can be concluded: (1) Indoor air velocity approximate $v=0.1 \mathrm{~m} / \mathrm{s}$, relative humidity approximate $40 \% \sim 50 \%$; (2) local residentces of towns and villages in winter agricultural fallow period, residents are mainly engaged in some housework and light manual labor, therefore the rate of metabolism of human body value $M=85 \mathrm{~W} / \mathrm{m}^{2}$ according to the average intensity of labor [7,9]; (3) According to lots of research results on the lives of local residents dress habits, considering the different age groups and different gender, the combinations of clothes $R$ clo average can be calculated, which can reach to 1.52 [clo] [9].

Thus, the calculation of subjective temperature $R$ clo can reach $15.7^{\circ} \mathrm{C}$. The comprehensive effect of other relative factors is considered, and the local indoor design and calculation temperature and the standard of the evaluation of comfort can be determined at $16^{\circ} \mathrm{C}$. Due to the subjective temperature calculation is based on the assumption of equal conditions of indoor air temperature and the average radiation temperature, and test results show that there are differences between the two, so the subjective temperature calculation is slightly different from the actual situation, which can be used for a rough design calculation and evaluation. 
Indoor Thermal Environment Analysis of Residence. We have tested two typical residences in Heilin village of Zhongwei city of Ningxia Province in January 2015. The results show that the indoor air velocity approximate $\mathrm{v}=0.1 \mathrm{~m} / \mathrm{s}$, the relative humidity approximate $40 \% \sim 50 \%$, the relative humidity and wind speed have little effect on the body heat comfort. The indoor air temperature test data for four rooms of two kinds of residences, including rooms with heating equipment and without heating of each kind of residences, are shown in Fig. 2:

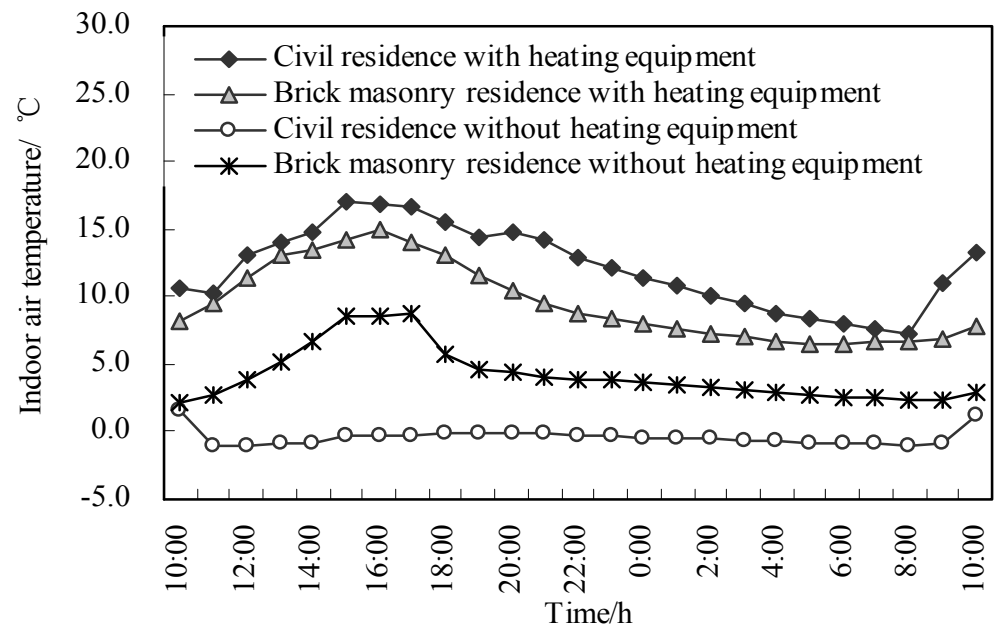

Fig. 2 indoor air temperature measurements of two typical residences

Fig. 2 shows that: when take certain measures of heating in the room, the average indoor air temperature of traditional residence can reach to $12.1^{\circ} \mathrm{C}$, while the new residential reached $9.5^{\circ} \mathrm{C}$, a difference of $2.6^{\circ} \mathrm{C}$; when the room under the natural condition, the indoor air temperature of civil residence can reach $0.4^{\circ} \mathrm{C}$, while the new brick masonry residence reached $4.2^{\circ} \mathrm{C}$, a difference of $4.6^{\circ} \mathrm{C}$; In addition, when the room under the natural condition, the indoor air temperature of civil residence is more stable than the new residence. Obviously, the indoor thermal quality of the new style residence is not totally higher than that of the traditional residence. Therefore, the new style residence need to be further improved, and the traditional civil residence still has the place of reference.

The above analysis show that there is a great difference between the indoor thermal environment of the two types of residence, and its influence factors come from various aspects. As far as outside climate conditions, the most important is the influence of solar heat gain, can be full and effective use of solar energy plays an important role in the indoor thermal environment quality [10,11]. In addition, the construction design and performance of the building envelope have a significant impact on the indoor thermal environment. The average indoor air temperature of civil residential heating-room is higher than that of brick masonry residence. Analysis of the reasons is the window area of civil residence is small and the windows are sealed well, so that the heat loss is small. For the unheated room, The indoor average air temperature of brick masonry residence is higher than that of civil residence, which is mainly because of the south window to wall ratio of brick masonry residence is larger, which is conducive to the indoor heat gain, therefore the performance of windows and doors and the south window to wall ratio have a greater influence on the indoor thermal environment. Under natural operating conditions, the civil residence is more stable than brick masonry residence. It is due to the influence from the insulation performance of building envelope, the heat transfer coefficient of adobe wall construction is smaller than the solid clay brick wall construction, making the heat preservation performance of adobe wall construction is more favorable and reducing the heat loss to a certain extent. Therefore the heat transfer coefficient of the wall plays an important role in improving the indoor thermal environment.

\section{Energy Saving Structural System Analysis}

New residence has been carried out significantly improved than traditional residence in heating mode (intermittent heating), building layout combinations of groups and so on, with a certain 
geographical adaptability. However, new residence needs to further improve in the building envelope and passive solar thermal utilization, etc.

Construction Types and Thermal Parameters of the Wall. The key to improving the efficiency of passive solar energy for the residences is to improve the thermal performance of the building envelope, and the heat transfer coefficient is the core indicators of the envelope construction performance [12]. According to the regional features, economic conditions and architectural features of the rural areas in Zhongwei city, the heat transfer coefficient of the exterior building envelope can be reduced by using non uniform wall construction $[13,14]$. Referenced literature [15], the heat transfer coefficient can be set for the slope roof insulation is approximate 0.4. The calculation results of the heat transfer coefficient of different wall constructions are shown in Table 3.:

Table 3. Heat transfer coefficient of different non-uniform wall construction

\begin{tabular}{|c|c|c|c|c|c|c|}
\hline $\begin{array}{l}\text { Construction } \\
\text { type }\end{array}$ & & Material & Thickness [mm] & $\begin{array}{l}\text { Heat conduction } \\
\text { coefficient } \\
{[\mathrm{W} /(\mathrm{m} \cdot \mathrm{K})]}\end{array}$ & $\begin{array}{l}\text { Density } \\
{\left[\mathrm{kg} / \mathrm{m}^{3}\right]}\end{array}$ & $\begin{array}{l}\text { Heat transfer } \\
\text { coefficient } \\
{\left[\mathrm{W} /\left(\mathrm{m}^{2} \cdot \mathrm{K}\right)\right]}\end{array}$ \\
\hline \multirow{6}{*}{$\begin{array}{l}\text { The first } \\
\text { construction } \\
\text { type }\end{array}$} & \multirow{3}{*}{$\begin{array}{c}\text { East, west } \\
\text { and north } \\
\text { walls }\end{array}$} & $\begin{array}{l}\text { Cement mortar (outer) } \\
+ \text { Cement (inner) }\end{array}$ & $20+20$ & 0.93 & 1800 & \multirow{3}{*}{0.41} \\
\hline & & Solid clay brick & $\begin{array}{c}120 \text { (exterior pages) } \\
+120 \text { (interior) }\end{array}$ & 0.81 & 1800 & \\
\hline & & Straw brick & 250 & 0.13 & 110 & \\
\hline & \multirow{3}{*}{ South wall } & $\begin{array}{l}\text { Cement mortar (outer) } \\
+ \text { Cement (inner) }\end{array}$ & $20+20$ & 0.93 & 1800 & \multirow{3}{*}{0.72} \\
\hline & & Solid clay brick & $\begin{array}{l}120 \text { (exterior pages }) \\
+120 \text { (interior) }\end{array}$ & 0.81 & 1800 & \\
\hline & & Straw brick & 120 & 0.13 & 110 & \\
\hline \multirow{6}{*}{$\begin{array}{c}\text { The second } \\
\text { construction } \\
\text { type }\end{array}$} & \multirow{3}{*}{$\begin{array}{l}\text { East, west } \\
\text { and north } \\
\text { walls } 1\end{array}$} & $\begin{array}{l}\text { Cement mortar (outer) } \\
+ \text { Cement (inner) }\end{array}$ & $20+20$ & 0.93 & 1800 & \multirow{3}{*}{1.01} \\
\hline & & Solid clay brick & $\begin{array}{l}120 \text { (exterior pages }) \\
+120 \text { (interior) }\end{array}$ & 0.81 & 1800 & \\
\hline & & Adobe & 360 & 0.72 & 2000 & \\
\hline & \multirow{3}{*}{ South wall } & $\begin{array}{l}\text { Cement mortar (outer) } \\
+ \text { Cement (inner) }\end{array}$ & $20+20$ & 0.93 & 1800 & \multirow{3}{*}{1.20} \\
\hline & & Solid clay brick & $\begin{array}{c}120 \text { (exterior pages }) \\
+120 \text { (interior) }\end{array}$ & 0.81 & 1800 & \\
\hline & & Adobe & 250 & 0.72 & 2000 & \\
\hline \multirow{3}{*}{$\begin{array}{l}\text { The third } \\
\text { construction } \\
\text { type }\end{array}$} & \multicolumn{2}{|c|}{$\begin{array}{l}\text { Cement mortar (outer) } \\
+ \text { Cement (inner) }\end{array}$} & $20+20$ & 0.93 & 1800 & \multirow{3}{*}{0.89} \\
\hline & \multicolumn{2}{|c|}{ Solid clay brick } & $\begin{array}{l}120 \text { (exterior pages }) \\
+120 \text { (interior) }\end{array}$ & 0.81 & 1800 & \\
\hline & \multicolumn{2}{|c|}{ EPS insulation board } & 20 & 0.041 & 20 & \\
\hline
\end{tabular}

Note: The heat transfer resistance for the inner surface of wall is $0.11\left(\mathrm{~m}^{2} \cdot \mathrm{K}\right) / \mathrm{W}$, the outer surface of wall is $0.04\left(\mathrm{~m}^{2} \cdot \mathrm{K}\right) / \mathrm{W}$, insulation layer correction coefficient of thermal conductivity is 1.1 [5]; The thermal parameters of wall material can be determined by the literature [5], [6].

Table 3 shows that the straw bale in the first construction type has a remarkable improvement on the thermal performance of building envelope. Straw and grass are renewable resources, which are easy to be obtained and are beneficial for energy saving and environmental protection. Taken 
together, grass brick combined with solid clay brick can be used as wall materials, which is suitable for the local residences.

Feasibility Analysis of Solar Heating. Considering the locally abundant solar radiation conditions, we can adopt the passive solar heating to effectively improve indoor thermal environment $[16,17]$. If the problem of heating in residential buildings can be solved by the passive solar heating depends on two factors, which need to comprehensive considerate the solar radiation intensity and the temperature difference between indoor and outdoor. For regions of where the solar radiation condition is better, but outdoor temperature is too low, using only solar heating does not necessarily satisfy the demand to effectively improve the indoor thermal environment when the house under the natural condition $[18,19]$. The average radiant temperature difference ratio $\overline{H T}$ reflects the influence of the outdoor air temperature and solar radiation intensity on the passive solar heating mode. The average radiant temperature difference ratio is more greater. The solar heating effect is more better. Thus, the average radiant temperature difference ratio of the coldest month South heating vertical in winter can be used as the criterion to estimate the feasibility of using passive solar heating in Ningxia region. The formula is shown in Formula (4). [18,20]:

$$
\overline{H T}=\bar{H} /\left(T_{\mathrm{i}}-T_{\mathrm{a}}\right)
$$

In the formula (4), $\bar{H}$ refers to the average solar radiation intensity, which is projected on the window surface (the collector member daylight opening) $\left[\mathrm{W} / \mathrm{m}^{2}\right]$, the calculation value according to the meteorological data of database can reach to $190.01\left[\mathrm{~W} / \mathrm{m}^{2}\right] ; T_{\mathrm{i}}$ refers to the indoor calculation temperature, which can be the subjective temperature of $16^{\circ} \mathrm{C} ; T_{\mathrm{a}}$ refers to the outdoor air average temperature of the coldest month, which is determined as below zero $5.2^{\circ} \mathrm{C}$ by the meteorological database.

According to the formula (4), the average radiant temperature difference ratio of the coldest month South heating vertical in winter is calculated as 9.0, which is higher than 8.0 , so there is the availability of solar energy according to the literature [18,21].

Effect Analysis of Solar Heating. The features of direct-gain solar system in residence including: more simple construction, more quick heating, more beautiful building, more flexible art, and lower cost in all the passive solar heating modes. The main essential principle is a process of solar thermal energy collection, storage, and release [22]. New local brick masonry residence has the sense of passive solar heating through increasing the windows to the south area compared with the traditional civil residence, but the new local brick masonry residence is lack of the scientific design and analysis. On the basis of investigation and analysis, this research has carried on some improvements to the passive collector system: (1) To increase window to wall ratio to 0.4 ; (2) To improve the properties of windows by using the PVC single frame double glass window, the heat transfer coefficient of which is $2.5\left[\mathrm{~W} /\left(\mathrm{m}^{2} \cdot \mathrm{K}\right)\right][5]$; (3) To ensure the rigor of the glass window design and installation in order to avoid the emergence of the loss of heat is greater than the gain of the sun's heat; (4) Try to reduce the loss of heat. On the one hand, we can add the insulation curtain to the window glass for the preservation of night heat; on the other hand, the wall material can be used with a special material which combined with solid clay brick and straw brick and the roofing should be treated with heat preservation.

Solar contribution rate as an important index for evaluating the thermal performance of a passive solar building. The solar contribution rate reflects the ability of passive solar building to rely on solar heating [23]. The reasonable solar contribution rate can reach a balance in the ability of the building to obtain the solar energy and the consumption of building heat. The formula is shown in Formula (5).:

$$
S H F=\frac{\text { Total net solar heat of solar residence }}{\text { The total heat consumption of solar residence at room temperature }} \%=\frac{S_{\mathrm{P}} \cdot A_{\mathrm{P}}}{q_{\mathrm{H} \cdot \mathrm{T}}} \%
$$


In the formula (5), $S_{\mathrm{p}}$ refers to the total solar radiation monthly average daily radiation of solar set system heat per unit area; $A_{\mathrm{P}}$ refers to the hot area of the collector; $q_{\mathrm{HT}}$ refers to the building envelope consumption of heat energy through unit construction area $\left[\mathrm{W} / \mathrm{m}^{2}\right]$, the concrete expression formula according to the literature [1] is shown in Formula (6).:

$$
q_{\mathrm{H} \cdot \mathrm{T}}=q_{\mathrm{Hq}}+q_{\mathrm{Hw}}+q_{\mathrm{Hd}}+q_{\mathrm{Hmc}}
$$

In the formula (6), $q_{\mathrm{Hw}}, q_{\mathrm{Hd}}, q_{\mathrm{Hq}}$ and $q_{\mathrm{Hmc}}$ separately refer to the heat transfer, which through the walls, roof, floors, windows and doors per unit time and is converted into the unit building area $\left[\mathrm{W} / \mathrm{m}^{2}\right]$.

In the calculation process of heat consumption, the indoor temperature can be determined as the subjective $16^{\circ} \mathrm{C}$; for the outdoor temperature, due to the envelope exterior surface is affected by the sun in different directions [24], in the calculation process, this interaction has been integrated into a single outdoor meteorological parameters, namely "Sol-air temperature" , which can be expressed as $t_{\mathrm{sa}}$. According to the literature [6,24], the formula is shown in Formula (7).:

$$
t_{\mathrm{sa}}=t_{\mathrm{e}}+\frac{q_{\mathrm{S}}+q_{R}}{\alpha_{\mathrm{e}}}-\frac{q_{\mathrm{e}}}{\alpha_{\mathrm{e}}}
$$

In the formula (7), $q_{\mathrm{e}}$ refers to the effective long wave radiant heat of the exterior surface; $\rho_{\mathrm{s}}$ refers to the solar radiation absorption coefficient for exterior surface of building envelope, which can be be identified as 0.74 [6]; $\alpha_{\mathrm{e}}$ refers to the heat transfer coefficient for exterior surface of building envelope, which can be be identified as $23.0\left[\mathrm{~W} /\left(\mathrm{m}^{2} \cdot \mathrm{K}\right)\right][6] ; q_{\mathrm{S}}$ and $q_{\mathrm{R}}$ separately refers to the ground reflection radiant heat and the solar radiation heat that are absorbed at the exterior surface of building envelope.

According to the data of typical meteorological year [2] and the literature [24], the coldest month (January) calculation results of Sol-air temperature and the sum of $q_{\mathrm{s}}$ and $q_{\mathrm{R}}$ in the region are shown in Table 4.:

Table 4. The average totals solar radiation and Sol-air temperature of the coldest month

\begin{tabular}{|c|c|c|c|c|}
\hline & South & East & West & North \\
\hline Average total radiation for vertical $\left[\mathrm{W} / \mathrm{m}^{2}\right]$ & 190.0 & 121.7 & 121.6 & 100.8 \\
\hline Sol-air temperature average value $\left[{ }^{\circ} \mathrm{C}\right]$ & -1.3 & -3.5 & -3.5 & -4.2 \\
\hline Outdoor air temperature $\left[{ }^{\circ} \mathrm{C}\right]$ & \multicolumn{4}{|c|}{-5.2} \\
\hline
\end{tabular}

The calculation results of solar contribution rate for the local existing new brick masonry residence and direct-gain solar system residence is shown in Table 5.: 
Table 5. Solar contribution rate of residences

\begin{tabular}{|c|c|c|c|c|c|c|c|c|}
\hline & \multirow{2}{*}{$\begin{array}{l}\text { South } \\
\text { window } \\
\text { to wall } \\
\text { ratio }\end{array}$} & \multirow{2}{*}{$\begin{array}{c}\text { Heat } \\
\text { transfer } \\
\text { coefficient } \\
\text { of exterior } \\
\text { windows } \\
{\left[\mathrm{W} /\left(\mathrm{m}^{2} \cdot \mathrm{K}\right)\right]}\end{array}$} & \multicolumn{2}{|c|}{$\begin{array}{l}\text { Heat transfer } \\
\text { coefficient of the } \\
\text { exterior wall } \\
{\left[\mathrm{W} /\left(\mathrm{m}^{2} \cdot \mathrm{K}\right)\right]}\end{array}$} & \multirow{2}{*}{$\begin{array}{l}\text { Heat transfer } \\
\text { coefficient } \\
\text { of roof } \\
{\left[\mathrm{W} /\left(\mathrm{m}^{2} \cdot \mathrm{K}\right)\right]}\end{array}$} & \multirow{2}{*}{$\begin{array}{l}\text { Total } \\
\text { net } \\
\text { solar } \\
\text { heat } \\
{\left[\mathrm{W} / \mathrm{m}^{2}\right.} \\
]\end{array}$} & \multirow{2}{*}{$\begin{array}{l}\text { The total } \\
\text { heat } \\
\text { consumptio } \\
\mathrm{n} \text { at room } \\
\text { temperature } \\
{\left[\mathrm{W} / \mathrm{m}^{2}\right]}\end{array}$} & \multirow{2}{*}{$\begin{array}{c}\text { Solar } \\
\text { contributio } \\
\text { n rate }\end{array}$} \\
\hline & & & $\begin{array}{l}\text { East, west } \\
\text { and north }\end{array}$ & South & & & & \\
\hline $\begin{array}{l}\text { Existing } \\
\text { new } \\
\text { residenc } \\
\text { e } \\
\end{array}$ & 0.3 & 6.4 & 1.54 & 1.54 & 1.47 & 22.8 & 114.3 & $20 \%$ \\
\hline $\begin{array}{l}\text { Direct- } \\
\text { gain } \\
\text { solar } \\
\text { system } \\
\text { residenc } \\
\text { e }\end{array}$ & 0.4 & 2.5 & 0.41 & 0.72 & 0.40 & 32.3 & 61.8 & $52 \%$ \\
\hline
\end{tabular}

The calculation results in Table 5 show that, the contribution of solar heating of residential buildings is increased from $20 \%$ to $52 \%$ by improving the passive solar collector system. With the solar contribution increasing, the solar heat of building and the building energy consumption were changed significantly. Solar heat of building from the original $22.76\left[\mathrm{~W} / \mathrm{m}^{2}\right]$ increased to 32.31 $\left[\mathrm{W} / \mathrm{m}^{2}\right]$, increased by $42.0 \%$. The building heat consumption decreased from $114.25\left[\mathrm{~W} / \mathrm{m}^{2}\right]$ to $61.76\left[\mathrm{~W} / \mathrm{m}^{2}\right]$, reduced by $45.9 \%$.

The above analysis show that, the efficiency of solar heating can be improved significantly by improving the design of envelope construction and thermal parameters and the passive solar set heat insulation efficiency of the building, so as to improve the indoor thermal environment quality of residential buildings in winter.

\section{Conclusions}

(1) Considering fully about the characteristics of rural residence in Ningxia, the indoor design and calculation temperature of $16^{\circ} \mathrm{C}$ can meet the demand of residents in indoor thermal comfort.

(2) The influence factors of indoor thermal environment are various, the main two aspects of which is the efficiency of a solar collector system and the envelope construction of a building.

(3) The average radiant temperature difference ratio of the coldest month South heating vertical in winter of the rural residence in Ningxia can reach to 9.0, which is higher than 8.0, so the local solar energy is available.

(4) The performance of solar collector system can be improved effectively by improving the design of residential construction, making the solar contribution rate increased form $20 \%$ to $52 \%$, which can improve the indoor thermal environment significantly and reduce the building energy consumption effectively.

(5) With the development of social economy and the continued deterioration of the ecological environment in western regions of our country, the contradiction between the indoor thermal environment improvement of residence, the energy consumption for heating and the protection of ecological environment is growing. The results of this study show that improving structural design of the residential building according to the local conditions is a useful idea to solve the sustainable development of the residential building. 


\section{Acknowledgements}

This work was supported by the National Natural Science Foundation of China (51278419), Shaanxi Provincial Social Development of Science and Technology Research Project (2012K12-04-01), Scientific Research Program Funded by Shaanxi Provincial Education Department (2013JK0945).

\section{References}

[1] JGJ26-2010 Design standard for energy efficiency of residential buildings in severe cold and cold zones, [S]. Beijing: China Architecture and Building Press, 2010. [In Chinese].

[2] Qingyuan Zhang, Joe Huang. Chinese standard meteorological database for buildings [M]. Machinery Industry Press, 2004. [In Chinese].

[3] Devrim Aydina, Zafer Utlub, Olcay Kincay. Thermal performance analysis of a solar energy sourced latent heat storage, [J]. Renewable and Sustainable Energy Reviews. Forum Vol. 50 (2015), p. 1213-1225.

[4] Karsten Voss. Solar energy in renovation-results and experience of international demonstration buildings, [J]. Energy and Building. Forum Vol. 32 (2000), p. 291-302.

[5] GB50176-2002 Thermal design code for civil building, [S]. Beijing: China Architecture and Building Press, 2002. [In Chinese].

[6] Jiaping Liu, Architectural Physics, Fourth ed. [M]. Beijing: China Architecture and Building Press, 2013. [In Chinese].

[7] Yiyun Zhu, Yanfeng Liu, Jiaping Liu. Thermal design of energy saving buildings in rural areas of northwest under the indoor uniform radiation filed, [J]. Acta Energiae Solaris Sinica. Forum Vol. 32 (2011), p. 1034-1039. [In Chinese].

[8] Hong Jin, Hua Zhao, Xiuping Wang. Research on the indoor thermal comfort environment of rural housing in winter in super-cold region, [J]. Journal of Harbin Institute of technology. Forum Vol. 38 (2006), p. 2108-2111. [In Chinese].

[9] Jiaping Liu, Liu Yang. Thermal design of a zero energy cave-dwelling solar house, [J]. Acta Energiae Solaris Sinica. Forum Vol. 20 (1999), p. 302-310. [In Chinese].

[10] J.H. Kampf, D. Robinson. Optimization of building form form solar energy utilisation using constrained algorithms, [J]. Energy and Buildings. Forum Vol. 42 (2010), p. 807-814.

[11]Zhang Q, Liang R, Liu J P. Rural houses with appropriate strategies in northwest China: a practice of ecological houses in Ningxia Province, [J]. Frontiers of Architecture and Civil Engineering in China, Forum Vol. 4 (2010).

[12] Dalong Liu, Jiaping Liu, Liu Yang. Thermal parameters of building envelope of energy efficiency building in severe cold climate, [J]. Journal of Xi'an University of Architecture and Technology (Natural Science Edition). Forum Vol. 6 (2014), p. 856-859. [In Chinese].

[13] GB/T 50824-2013 Design standard for energy efficiency of rural residential buildings, [S]. Beijing: China Architecture and Building Press, 2013. [In Chinese].

[14] Morteza Khalaji Assadi, Abdollah Khalesi Doost. Ali Asghar Hamidi, Maryam Mizani, Design construction and performance testing of a new system for energy saving in rural buildings, [J]. Original Research Article Energy and Buildings. Forum Vol. 43 (2011), p. 3303-3310.

[15] "The architectural design data set "editorial board. Architectural design data set, second ed., [M]. Beijing: China Architecture and Building Press, 1996. [In Chinese]. 
[16]Ezra Sohar Men. Microclimate and society: Physiological requirements of the human body for comfortable indoor climate, [J]. Original Research Article.Energy and Buildings. Forum Vol. 4 (1982), p. 149-154.

[17] Sanja Stevanović. Optimization of passive solar design strategies, [J]. A Review Article Renewable and Energy Reviews. Forum Vol. 25 ( 2013), p. 177-196.

[18] Yang Zhang, Liuyuan Wu. Research on the division of distributing regions of passive solar houses with zero-auxiliary heating source, $[\mathrm{J}]$. Journal of Xi'an University of Architecture and Technology. Forum Vol. 32 (2000), p. 227-233. [In Chinese].

[19] Georgios Tsalikis, Georgios Martinopoulos. Solar energy systems potential for nearly net zero energy residential buildings, [J]. Original Research Article Solar Energy. Forum Vol. 115 (2015), p. 743-756.

[20] Jiaping Liu, Gaochao Du. Thermal design of passive solar buildings without using supplementary heating source, [J]. Journal of Xi'an University of Architecture and Technology. Forum Vol. 4 (1995), p. 370-374. [In Chinese].

[21] Jianren Sang, Yulan Liu, Li Lin. Comprehensive evaluation on solar radiation characters and potential of solar energy utilization in Ningxia, [J]. Journal of Desert Research. Forum Vol. 26 (2006), p. 122-125. [In Chinese].

[22] Yuanzhe Li. Thermal design manual of passive solar house, [M]. Beijing: Tsinghua University press, 1993. [In Chinese].

[23] Qun Zhao, Guiwen Li. The influence factor of solar contribution rate of passive solar building, [J]. Low Temperature Architecture Technology. Forum Vol. 1 (2008), p. 113-114. [In Chinese].

[24] Qisen Yan, Qingzhu Zhao. The thermal process of buildings, [M]. Beijing: China Architecture and Building Press, 1986. [In Chinese]. 